\title{
The Hydrogen Energy Infrastructure Development in Japan
}

\author{
Sergei Popov ${ }^{1 *}$, Oleg Baldynov ${ }^{1}$ \\ ${ }^{1}$ Melentiev Energy Systems Institute of the Siberian Branch, Russian Academy of Sciences, Lermontov st. 130, Irkutsk, Russia
}

\begin{abstract}
The actual start of the full-scale hydrogen energy infrastructure operations is scheduled to 2020 in Japan. The scope of factors and policy for the hydrogen infrastructure development in Japan is made. The paper provides observation for the major undergoing and already done projects for each link within hydrogen infrastructure chain - from production to end-user applications. Implications for the Russian energy policy are provided.
\end{abstract}

\section{Introduction}

The article reviews the current state of the hydrogen energy infrastructure (HEI) development in Japan. The fact that Japan is the most suitable economy for starting the construction and operations of a full-fledged HEI is indicated by providing reasons and circumstances. Briefly, the areas of research and development (R\&D) in the field of hydrogen energy are discussed, the organisation of this process at the national level are considered, the characteristics of the main existing (or under construction) HEI facilities are given. In addition, the main characteristics and production volumes for a number of end-use hydrogen energy devices are indicated. In conclusion, the role of HEI in the energy policy of Japan and within Northeast Asia is emphasized, the long-term consequences for Russia from the development of HEI are estimated.

\section{Why Japan?}

Japan's energy strategy is to utilise domestic resources in order to reduce dependence on primary energy imports (Fig.1) as much as possible. The country has one of the world's largest financial capital, successfully operating organisational structures for technological development and industrial entrepreneurship, qualified research and industrial personnel, high quality education system. Japan made the bet on substitution of energy import by innovative technologies. The leading industrial economy if East Asian region decided to increase the efficiency of imported energy utilisation, as well as domestic renewable energy sources by utilising country's R\&D capabilies, hi-tech industrial competence, investment institutions and scilled manpower. In addition, Japan is expecting to gain a competitive advantage in the energy technology markets in the coming era of higher prices for energy resources.

According to the BP's experts, oil proven reserves on the Earth will last for 50 years at their current level of production, gas-for 53 years, coal-for 134 years [1]. By pessimistic assumptions, the price of a barrel of crude oil will reach US\$150 (in 2016 prices), US $\$ 200$ by 2030 and US\$225 by 2040. The so-called "realistic" estimations by EIA DOE are US\$75, US\$85 and US $\$ 110$ per barrel, respectively [2]. The price of gas in Japan for business-as-usual case is estimated at 325 dollars per 1000 cubic meters of gas for 2020, 400 in year 2030 and 450 in year 2040 [3].

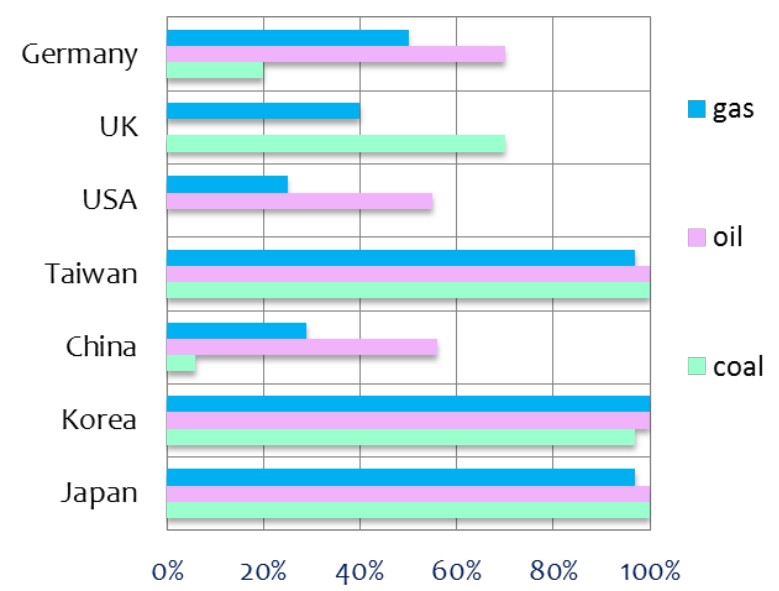

Fig. 1. Dependency on energy import for some industrialised economies.

Hydrogen energy infrustructure is considering as complimentary to electricity infrastructure, i.e. power systems (PS), in a sence of energy transportation, production source diversity and wide application scope. The main difference between HEI and PS is inherited storage feature for the former, since hydrogen is an energy carrier, which does not require an established physical connection between the sender and the receiver, in contrast to the power transmission. Hydrogen transportation system could be presented by pipelines as well as by shipping, road, railroad, and even aeronautical modes.

*Corresponding author: popovsp@isem.irk.ru 
That makes a great difference in terms of energy transportation and utilisation costs, which is becoming crucial for long-distance energy deliveries and technical systems' regime control.

It is impractical to transmit electricity to Japan over very long distances from overseas countries. The electric power stored in batteries declines continuously over time due to natural discharge, whereas hydrogen can be stored for long periods in criogenic tanks, and acceptably enough for the most of transportation and residential services in compressed mode. This features priovides hydrogen high flexibility of utilisation and storage. The high degree of the spatio-temporal freedom is one of hydrogen's biggest advantages over electricity power applications. Driving range of fuel-cell vehicles is over three to five times greater then for comparable electric vehicle. Moreover, it takes several hours for an electric battery to charge, while full charging time for the car's hydrogen fuel cell is three minutes [4].

However, while hydrogen is considered as a promising energy carrier to complement electric power and substitute fossil fuels, there are some technological obstacles for its introduction. Regardless of the implementation method, electricity provide main contribution (70-90\%) to the cost of hydrogen produced by the electrolysis method. Moreover, unlike the hydrogen production from natural gas, the price of hydrogen will not depend significantly from the electrolysis plant's capacity scale. Thus, the main factor determining the competitiveness of the electrolyzer is not the cost, but the efficiency of its operation, i.e. technological maturity.

Since hydrogen's energy density per volume is about one-third that of a natural gas, finding a means to maintain hydrogen at high density during transportation and storage is a challenge. While there are a variety of ways to transport and store hydrogen, transportation of hydrogen as liquid or organic hydrides is promising for the overseas shipments.

In Japan the development of hydrogen-related technologies has reached such an advanced stage that the demonstration project phase of national holistic hydrogen energy infrastructure has began. The purpose of the HEI development is to demonstrate technologies, related to the use of a new energy carrier - hydrogen for three important parties: population, authorities, and business.

The purpose of demonstration projects is to make industry, consumers and general public accustome to the understanding of the technological preparedness for the commercialisation of the hydrogen technologies. That stage is necessary for bold energy policy development towards introducing less carbon-related energy systems, ending up in a fully renewable-based energy supply at the late of this centure.

Along with the implementation of promotional and advocacy functions, the demonstration projects phase is called upon to reveal the shortcomings of technologies and focus on the most effective and promising areas, taking into account the experience of their application in real operating conditions.

The demonstrational project at the national scale is a major treshold for international community to check technological level and provide opportunities for nonbiased assessments of hydrogen energy, being outgrew industrial testing stage. In this context, HEI is referred to the infrastructure chain to produce, transform into different physical states, transport and final energy consumption of hydrogen as an energy carrier, in order to provide useful energy service for buildings, transportation, and industry.

Demonstration of the whole, full-fledged HEI chain is important. Final energy consumers should be prepared to shift from traditional fuels to hydrogen. Yet another non-biomass renewable fuel should back buildings in a need of heat and power supply, in addition to renewable energy. Transportation systems should have more options for diversified mix of petroleum, natural gas and electric battery vehicles. At a final stage, industrial processes should demonstrate technological ability to shift from fossil fuels to hydrogen.

\section{Major actors}

The main stakeholders within the process of the HEI development in Japan are the state, represented by the government at the national, prefectural and municipal levels, large production, financial and technological corporations.

The National Government is concerned about the general administration and organisation of the comprehensive $R \& D$ process. There are several institutions under the umbrella on the New Energy and Industrial Technology Development Organisation (NEDO), in which business is involved at voluntary basis to deal with all aspects of the hydrogen energy technological chain. Currently for the 2015-2020 planning term there are three major themes:

- Technology Development for the Realization of Hydrogen Society;

- Technology Development for Large-Scale Hydrogen Systems;

- Demonstration of the Hydrogen Supply Chain by Organic Chemical Hydride Method Utilizing Unused Energy.

The Ministry of Economy, Trade and Industry of Japan (METI) established the Council for a Strategy for Hydrogen and Fuel Cells. The Strategic Roadmap for Hydrogen and Fuel Cells was developed under the authority of that Council, being revised in March 2016. The roadmap states the importance to establish a hydrogen supply system with low carbon dioxide emissions, setting this as a final goal to be achieved [5]. In the Basic Hydrogen Strategy scenario to reach some important markers in year 2030 is considered:

- commercial stage of hydrogen power generation at 16 cent per $\mathrm{kWh}$ (estimation was made for $1 \mathrm{GW}$ of power capacity unit);

- 3 USD per kg of hydrogen at retail station dispencer price;

- some $800 \mathrm{~K}$ fuel cell vehicles, 1200 buses and $10 \mathrm{~K}$ forklifts; more than five millions residential users (or ten percent of the Japanese households) [6]. 
Several large Japanese industrial companies participate in the hydrogen technologies commercialisation process, see Table 1.

Table 1. List of some important corporations involved in hydrogen energy infrastructure development in Japan.

\begin{tabular}{|l|l|}
\hline \multicolumn{1}{|c|}{ Company } & \multicolumn{1}{|c|}{ Industry } \\
\hline Kawasaki & $\begin{array}{l}\text { energy, ship building, power plant } \\
\text { engineering }\end{array}$ \\
\hline Toshiba & $\begin{array}{l}\text { energy, power plant engineering, } \\
\text { renewable energy, nuclear }\end{array}$ \\
\hline Mitsubishi & energy, metals, machinery, chemicals, \\
\hline $\begin{array}{l}\text { Ishikawajima- } \\
\text { Harima (IHI) }\end{array}$ & shipbuilder, aerospace, energy \\
\hline Marubeni & $\begin{array}{l}\text { traiding, chemicals, energy, metals and } \\
\text { mineral resources, transportation } \\
\text { machinery, power projects and } \\
\text { infrastructure, machinery }\end{array}$ \\
\hline Mitsui & shipping, trading \\
\hline Chiyoda & $\begin{array}{l}\text { hydrocarbons, engineering, chemistry, } \\
\text { energy }\end{array}$ \\
\hline Iwatani & $\begin{array}{l}\text { energy centering on gases, welding, } \\
\text { metals, mineral resources }\end{array}$ \\
\hline $\begin{array}{l}\text { Nippon Yusen } \\
\text { Kabushiki } \\
\text { Kaisha }\end{array}$ & shipping \\
\hline $\begin{array}{l}\text { Taiyo Nippon } \\
\text { Sanso }\end{array}$ & energy centering on gases, welding \\
\hline $\begin{array}{l}\text { Air Liquide } \\
\text { Japan }\end{array}$ & energy centering on gases \\
\hline $\begin{array}{l}\text { Numerous oil } \\
\text { and gas, power } \\
\text { companies }\end{array}$ & energy centering on gases \\
\hline Toyota & automaker \\
\hline Nissan & automaker \\
\hline Honda & autor \\
\hline
\end{tabular}

Kawasaki Heavy Industries is engaged in hydrogen transportation, incl. liquefaction, marine transport of liquefied hydrogen; road transport of liquefied and compressed hydrogen; hydrogen storage and hydrogen utilisation, including middle and large-scale power generation facility [7].

Toshiba is engaged in water electrolysis (including systems powered by photovoltaic and wind energy); hydrogen storage; residential cogeneration systems; large capacity hydrogen fuel cell power generation. Toshiba Group aims to increase the hydrogen-related business to almost one billion dollars by 2020 [8].

Iwatani intends to play an important role in expanding the use of hydrogen energy based on their own technology to transport, store, and supply hydrogen, and copmany's know-how on construction and operation of hydrogen stations [9].

Chiyoda Corporation makes a bet on its "SPERA Hydrogen” technology, which allows bulk hydrogen transportation in chemically bound state at normal temperature and pressure [10].

Panasonic made household fuel cell, commercially available at the Japanese market since 2009. This product uses hydrogen, extracted from LPG or sity gas, to make electricity and hot water in residential and/or office buildings [11].

Through the mediation of Japanese government, corporations combine efforts in developing crucial elements, major subsystems, or comprehensive hydrogen energy systems.

Toshiba, Tohoku Electric Power and Iwatani are developing the world's largest $10 \mathrm{MW}$ hydrogen energy system project in the Fukushima prefecture [12]. This project will demonstrate hydrogen solutions for the whole supply chain - from production to utilisation of hydrogen; will gain experience on using hydrogen energy systems to stabilize electricity grids, and will contribute to the early establishment of transportation, storage and supply of industrial hydrogen [13].

Kawasaki joined forces with Iwatani, J-Power and Shell Japan to form the Hydrogen Energy Supply-Chain Technology Research Association (HySTRA). HySTRA aims to create a commercial liquefied hydrogen supply chain from overseas, which utilises original technology for long-range mass transportation and handling of liquefied hydrogen [14].

Eleven companies in March 2018 announced their joint establishment of Japan Hydrogen Mobility (JHyM) to boost development of hydrogen stations [15]. The ultimate goal of JHyM is to smoothly increase the number of fuel cell vehicles (FCV) on the roads in Japan, and thus to sustainability. Additional goal is to establish the retail hydrogen station's business. It is the world's first collaboration in which hydrogen infrastructure developers, automakers and investors are involved in.

"ENE-FARM" is is the positive outcome of the micro- and small coheneration plants (CHP) promotion project by METI. At this project Toshiba, Panasonic, Aisin Seiki, Muira, and Denso participate in a microscale segment, while Mitsubishi, Hitachi, Fuji, Bloom Energy deal with mini CHP in $20 \mathrm{~kW}$ to $250 \mathrm{~kW}$ scale [16].

\section{Plans to establish a hydrogen society}

The 2011 catastrophic events in Japan - the Great East Earthquake and Tsunami, coupled with Fukushima nuclear disaster, had been forced Japan to look for the revision of the country's energy strategy. Intensive and thorough consultations within government, industry and expert society lead to the decision to implement Hydrogen Society plan. The Japanese government is working with plans to establish a functioning hydrogen society, to promote the use of hydrogen fuel for energy and transportation.

One of the primary goals is significantly reduce the cost of hydrogen fuel to one-fifth of what it does currently. Hydrogen fuel will play a major role in Japan's national energy security, while it will be able to deal with climate change by distancing itself from fossil fuels [17].

Currently, the list of organisations involved in decision-making processes and their implementation consists of government, business and social structures [18]:

1) Ministry of Economy, Trade and Industry (METI);

2) New Energy and Industrial Technology 
Development Organization (NEDO);

3) The Association of Hydrogen Supply and Utilization Technology (HySUT);

4) Fuel Cell Commercialization Conference of Japan(FCCJ).

5) Next Generation Vehicle Promotion Center(NEV)

The Strategic Roadmap for Hydrogen and Fuel Cells was articulated in June 2014, and almost immediately, the need for an audit has been identified. That task has been done by the Agency for Natural Resources and Energy (ANRE of METI). The Revised Version of the Strategic Roadmap for Hydrogen and Fuel Cell was released in March 2016. The new targets and specified efforts to be made had been emphasised. The reasons where high rate of dissemination for the households' fuel cells, the launch of fuel cell vehicles onto the market, and steady progress in hydrogen stations construction.

In addition to previously stipulated strategy, more specific indicators for fuel cells (both household and transportation types) and hydrogen stations were adopted, while the use of renewables for hydrogen production and large-scale hydrogen-based power generation was postponed [19].

Here are highlights of the revision:

1) The future price targets for household fuel cells were clarified

- PEFC (polymer electrolyte fuel cells): 800 thousand yen by 2019;

- SOFC (solid oxide fuel cells): one million yen by 2021.

2) Targets for fuel cell vehicles dissemination were set

- About 40 thousand vehicles by 2020, about 200 thousand vehicles by 2025, and some 800 thousand vehicles by 2030, in total.

3) Targets for the hydrogen stations construction were set

- About 160 stations by 2020 and some 320 stations by 2025.

4) Descriptions concerning hydrogen power generation were fleshed out.

5) It was decided that technical and economic challenges would be discussed in relation to the utilisation of hydrogen generated by renewable energy.

The commitment to hydrogen in part is based on the exceptional success of Japan's commitment to residential fuel cells. The ENE-FARM program demonstrated the capability of fuel cells technology and the capacity of developers to improve their products rapidly given early market obstacles. After subsidy was cancelled in March 2015 [20], the government set targets of 1.4 million residential units by 2020 and 5.3 million by 2030 (about $10 \%$ of Japan's homes) [21].

\section{Hydrogen infrastructure: status quo}

Demonstration tests differ from industrial tests in that they use an approved and reliable technology in order to give an opportunity to independently verify the capabilities of the technology and more accurately assess its technical and economic characteristics. Such efforts should be regarded as the first step towards the commercialisation of technology.

\subsection{Hydrogen energy systems and Auxilliary infrastructure}

\subsubsection{The hydrogen system in Fukushima Prefecture}

Three companies start the development of large hydrogen energy system in Fukushima Prefecture in August 2017. The construction site for the hydrogen factory and solar panels were selected at abandoned nuclear plant site. New facilities is $10 \mathrm{MW}$ hydrogen production plant. The system will demonstrate the advantages of hydrogen as solution in grid balancing and as a reliable hydrogen gas supply. Hydrogen produced at the facility frpm renewable energy will be used primarily to supply fuel-cell vehicles.

One disadvantage of renewable energy is the difficulty to ensure stable power supply. The Fukushima hydrogen system will attempt to get around this problem by converting electricity generated from renewable energy into hydrogen because the gas is easier to store and transport. Hydrogen production are expected to begin by 2020 [22, 23].

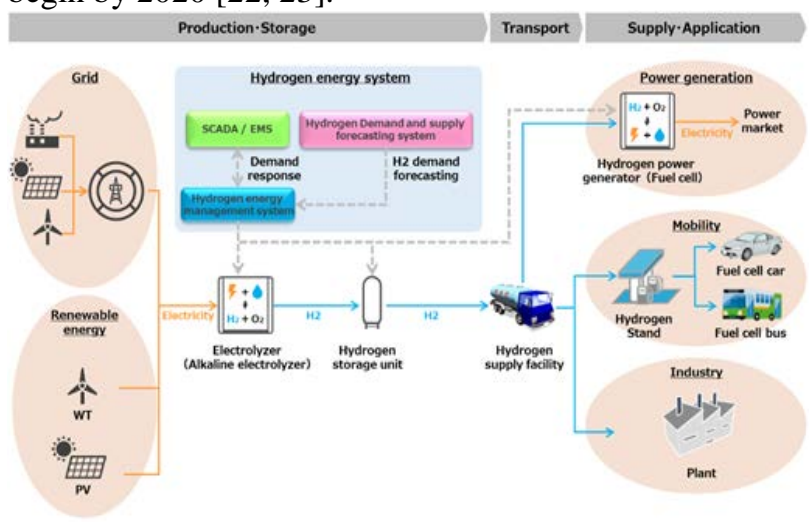

Fig. 2. The hydrogen system in Fukushima Prefecture.

\subsubsection{The hydrogen system in Hokkaido Prefecture}

a) "Power to Gas" system

In November 2017 a "Power to Gas" hydrogen energy system project starts in Tomamae Town, Hokkaido. The demonstrations' goals are to develop a new energy system and business model, which improve the utilisation of wind power by effectively converting unstable part of the power to hydrogen for thermal application, which include households cogenerating systems [24].

The main objectives of the demonstration are to verify [25]:

- the forecasting system's accuracy in forecasting wind power generation and the control system's ability to optimally split electricity into stable electricity for grid and unstable electricity for hydrogen production

- the performance of the electrolyzer that uses fluctuated electricity from wind power generation 
- the performance of hydrogenation system, which converts hydrogen into $\mathrm{MCH}$, and dehydrogenation system, which regenerates hydrogen from $\mathrm{MCH}$

- the economic feasibility of the demonstration model.

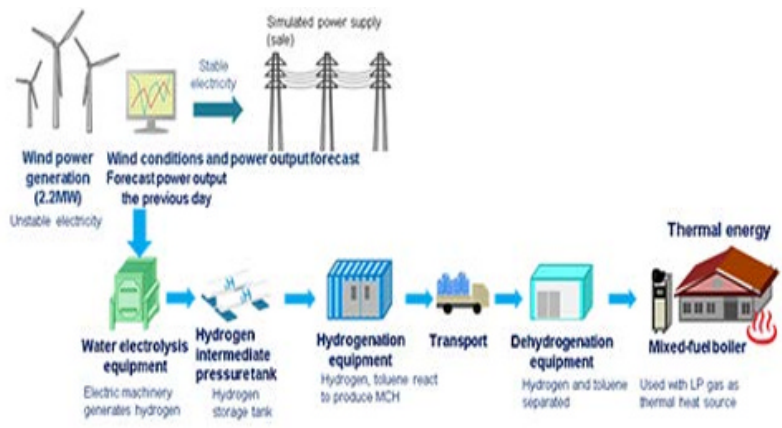

Fig. 3. "Power to Gas" project in Tomamae Town, Hokkaido.

Table 2. Role of partners within "power to gas" demonstration project.

\begin{tabular}{|l|l|}
\hline \multicolumn{1}{|c|}{ Partner } & \multicolumn{1}{|c|}{ Roles } \\
\hline $\begin{array}{l}\text { Toyota Tsusho } \\
\text { Corporation }\end{array}$ & $\begin{array}{l}\text { Lead company for demonstration } \\
\text { project, analyze business feasibility, and } \\
\text { create future business plans. }\end{array}$ \\
\hline $\begin{array}{l}\text { NTT Facilities, } \\
\text { Inc. }\end{array}$ & $\begin{array}{l}\text { Develop system to forecast wind } \\
\text { conditions and electric power generation } \\
\text { from wind turbines. }\end{array}$ \\
\hline $\begin{array}{l}\text { Kawasaki } \\
\text { Heavy }\end{array}$ & $\begin{array}{l}\text { Develop and operate the water } \\
\text { electrolyzer to produce hydrogen. } \\
\text { With NTT Facilities, develop and } \\
\text { operate the control system (integrated } \\
\text { controller) to optimize efficiency of the } \\
\text { entire system. }\end{array}$ \\
\hline $\begin{array}{l}\text { Hrein Energy } \\
\text { Inc. }\end{array}$ & $\begin{array}{l}\text { Develop and operate the hydrogenation } \\
\text { system and the dehydrogenation system. } \\
\text { Operate the mixed-fuel boiler that uses } \\
\text { hydrogen for heat generation. }\end{array}$ \\
\hline Technova Inc. & $\begin{array}{l}\text { With Toyota Tsusho, analyze business } \\
\text { feasibility and create future business } \\
\text { plans. }\end{array}$ \\
\hline $\begin{array}{l}\text { Muroran } \\
\text { Technolitute of } \\
\text { Wehydrogenation catalysts to improve } \\
\text { the performance of dehydrogenation } \\
\text { system. }\end{array}$ \\
\hline
\end{tabular}

\section{b) Hydrogen utilisation system}

A hydrogen utilisation system, suitable for the local characteristics in Kushiro city, Hokkaido, has started in May 2018. Electricity from the small hydropower plant will be used to electrolyze water and separate hydrogen at a rate about $35 \mathrm{Nm} 3$ per hour. The hydrogen will be transported to generate electricity with buiding's pure hydrogen fuel cell systems, and use as fuel for fuel cell vehicles [26].

\subsubsection{Mobile stand-alone power generator}

Demonstration operation of $\mathrm{H}_{2}$ One, an independent energy supply system based on renewable energy and use of hydrogen as a fuel for power generation, started in Kawasaki. Electricity generated from the photovoltaic installations is used to electrolyze water and produce hydrogen, which is then stored in tanks and used in fuel cells that produce electricity and hot water. In normal, non-emergency operation, hydrogen energy management system is used to contribute to peak shift, which reduces demand for mains power at times of high demand, through optimised control of hydrogen production, power generation and storage [27].

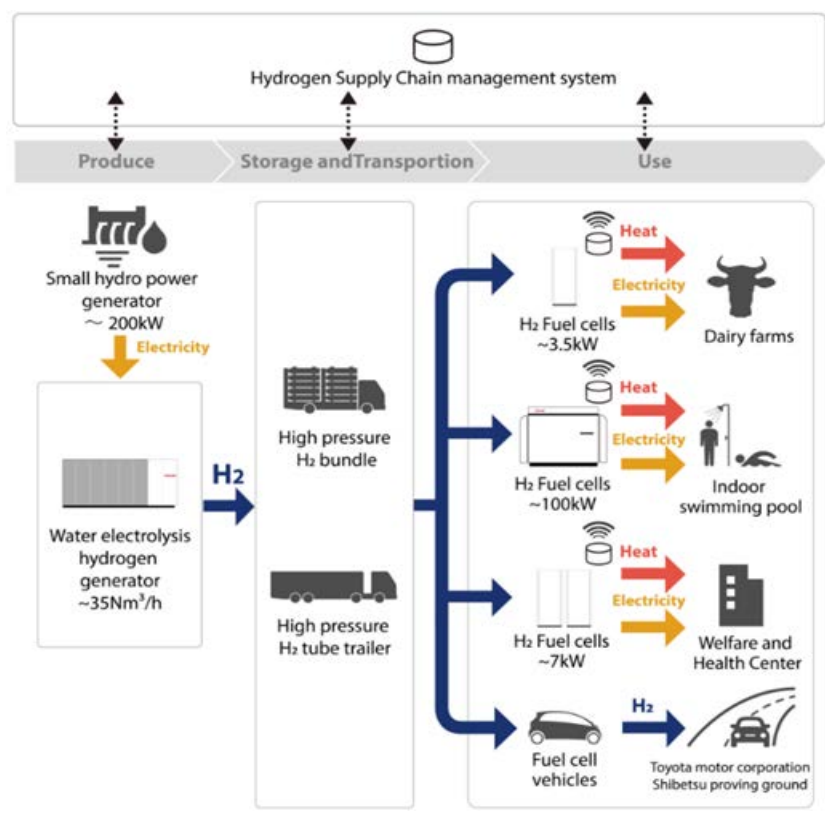

Fig. 4. Low-Carbon Hydrogen Sypply Chain Demonstration Project.

\subsubsection{Hydrogen transportation}

\section{a) $A H E A D$ project}

A consortium of Japanese companies (Chiyoda, Mitsubishi, Mitsui, Nippon Yusen) plans to launch the relatively small-scale demonstration project aims to import up to 210 tonnes of hydrogen to Japan in liquid form at ambient temperature and pressure.in 2020 . Consortium will build a plant to generate liquid hydrogen in Brunei and a plant in Kawasaki to process cargoes back into gas. Hydrogen gas will be used as fuel for $1 \mathrm{MW}$ gas-fired turbine.

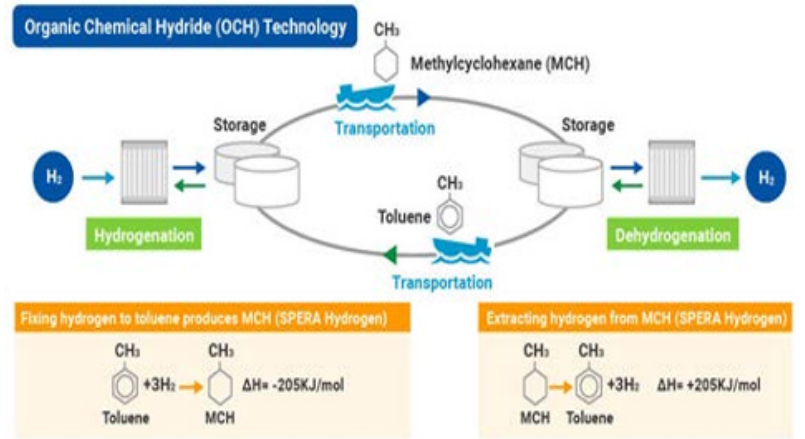

Fig. 5. AHEAD Demonstration Project.

The project is expected to cost several billion yen. Two thirds of the cost will be subsidised by the Japanese Government, a consortium official said [27, 29]. 
AHEAD is an acronym for Advanced Hydrogen Energy Chain Association for Technology Development [30].

\section{b) HySTRA's Australian hydrogen import to Japan}

The project is aimed at establishing supply chain to deliver massive amounts of hydrogen in a stable way, in line with efforts to develop carbon-free society in Japan. Under the project, Australian brown coal will be gasified to extract hydrogen, which will be exported to Japan after being liquefied. Shipments of hydrogen are likely to start around 2020. The consortium aims to put the project into the commercial phase in 2030 [31]. Kawasaki estimates that if $20 \%$ of Japan's total electricity will be generated from hydrogen in 2050, Japan would need around 80 liquid hydrogen $\left(\mathrm{LH}_{2}\right)$ carriers [32].

\subsection{Hydrogen distribution}

\subsubsection{Japan $\mathrm{H}_{2}$ Mobility}

Eleven companies in March 2018 announced their joint establishment of Japan hydrogen Mobility (JHyM) to boost development of hydrogen stations for fuel cell vehicles in Japan [33]. Consortium's objective is to attract new investors and station operators to support the development of a network of hydrogen stations in Japan. The target is to provide 80 new hydrogen stations in four years.

Infrastructure to deliver hydrogen fuel is critical for small and medium consumers, expecially for car owners. While stationary equipment is less sensitive to the charging time, it is matter of efficiency for road transportation. In 2008 to fill the car with hydrogen used to take about 30 minutes, but in 2017 it took ten times less.

As far as in March 2004 there were some 50 mobile units (cars and trucks), served by 10 hydrogen dispencer units, in Japan. There where 17 hydrogen stations in Japan at the end of 2012; in the middle of 2015 already 23 hydrogen retail stations was open to the public [34, 35]. According to official data, the 101 hydrogen stations serve around 2,400 fuel-cell vehicles in Japan, as of March 5, 2018 [36].

\subsubsection{Serving rural area}

Hitachi and Marubeni have been created partnership to tap into the growing demand for hydrogen fuel throughout rural areas of Japan in high-pressure cylinders. In the future, undertaking aims to serve almost half of all households in Japan that currently lack access to city gas [37].

\subsubsection{Serving rural area}

Honda started to build new type of hydrogen fuel stations network (approximately one hundred by 2020) throughout Japan. New fuelling stations will be more efficient at producing hydrogen fuel on-site, and will pressurise gaseous hydrogen using a mechanical compressor. This allows the stations to be much smaller and quieter, which could make them attractive for use in large, densely populated metropolitan areas.

Most importantly, the new hydrogen fuel stations will be less expensive. Conventional station cost is up to \$4.4 million, while Honda's (with government subsidies factored in) as much as $\$ 600,000$ [38].

\subsubsection{A model hydrogen refueling station for regional cities}

Iwatani opens the commercial hydrogen refueling station, the first in Okayama Prefecture, which is characterised by reduced construction costs with space saving packaged equipment. These approaches allow reducing installation footprint and reduce construction costs by limiting the on-site construction activity. Future increases in vehicle filling volume linked to the widespread uptake of FCV can be handled by increasing compressed hydrogen storage capacity. The station is a model hydrogen refueling station for future roll-out to regional cities, as well as for urban areas subject to numerous land restrictions [39].

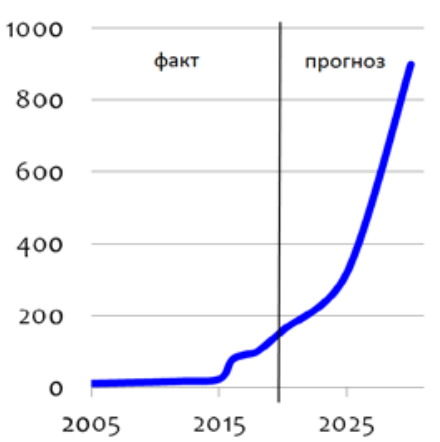

Fig. 6. Number of hydrogen filling stations in Japan, history and outlook to 2030 .

\subsection{Hydrogen consumers - auto, buildings, power generators}

\subsubsection{Buildings cogeneration by fuel cells}

Beginning in 2005 NEDO installed nearly 3,500 fuel cell systems in various homes. The beginning of fuel cell cogeneration systems "ENE-FARM" sales for residential use started in 2009, a worldwide first. More than 220,000 units have been installed since the program began in 2009.

The price for proton exchange membrane units has been cut by two-thirds to a little over JPY 1 million, with the target set to JPY 800,000 by 2019 . The government is considering ways to improve the uptake in multifamily housing units.

Olympic Village to be powered entirely by hydrogen fuel cells in order to showcase the capabilities of new technology. After the Olympic Games are completed, it will be converted into a real town that derives power from renewable energy systems that the Japanese government has established [40]. 


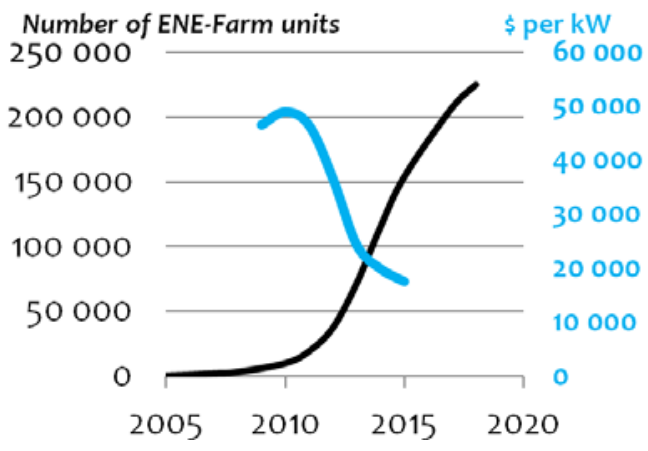

Fig. 7. Statistics of the ENE-FARM installations in Japan.

\subsubsection{Distributed power generation by fuel cells}

Hitachi Zosen Corporation is conducting a demonstration test for the market introduction of a solid oxide fuel cell (SOFC) power-generating system for commercial and industrial use. The system is installed in two places in Osaka under actual circumstances to evaluate its safety and reliability. The system is a smallscale unit designed for distributed power generation. This demonstration test is part of a joint effort between Osaka Prefecture and Osaka City [41].

\subsubsection{Preparing for mass production}

Toyota is preparing to ten-fold production of fuel cells and hydrogen tanks enhance after 2020. As technology, fuel cells are mature and ready to scale up. To prepare for this growth, the company unveiled plans for two new major facilities: building for expanding fuel cell stack mass production, and a new line to manufacture high-pressure hydrogen tanks. Manufacturing both components at scale is critical to achieving lower system costs, start of operations is expected around 2020 [42].

$\mathrm{H}_{2} \mathrm{One}^{\mathrm{TM}}$ by Toshiba is now operational at JR Station in Kawasaki City, at the Marien public facility, HigashiOgishima-Naka Park in the Kawasaki Port area, at artificial island and pier in the Port of Yokohama [43]. Toshiba's fuel cell product line-up includes units that go up to $100 \mathrm{~kW}$, and are installed in convenience stores, municipal wholesale flower and vegetable markets, farm and local swimming pools [44].

The Miyagi prefectural government chose $\mathrm{H}_{2} \mathrm{One}^{\mathrm{TM}}$ for its Rakuten Kobo Stadium in Sendai. On normal days, the unit will generate electricity to power the stadium's display, and during emergencies it will keep the regional radio station in the stadium in operation to provide essential information for disaster recovery.

Railway station, from which 80,000 people take train every day, depends on $\mathrm{H}_{2} \mathrm{One}^{\mathrm{TM}}$ to provide uninterrupted, off-grid energy supply in case of emergencies to light parts of the station concourse and its lavatories. In winter, hot water from the system is used to warm benches at the station [45].

The local hydrogen system is installed at Tokyu Construction Institute of Technology and start operation since December 2017. This system utilises a photovoltaic system in the building to electrolyze hydrogen. Its power the building's air-conditioning systems, while hot water is used in the building's hotwater supply system [46].

A pure hydrogen fuel cell system (producers are Toshiba and Showa), has been installed in a Kawasaki King Skyfront Tokyu REI hotel. Hydrogen to fuel the system is extracted from recycled used plastics by Showa, and the fuel cell helps to meet the energy needs of the hotel, where hot water is cogenerated with electricity [47].

\subsubsection{Electrolyser}

Hitachi Zosen Corporation delivered a Hydro Spring hydrogen generation system (solid polymer electrolyte, $24 \mathrm{Nm}^{3} / \mathrm{h}$ ) for Toyota Motor Kyushu's Miyata Plant. This project was designed to allow the operation of fuel cell-powered forklifts using hydrogen generated from renewable energy. The system produces hydrogen with purity levels between 99.999\% and 99.9999\% [48].

\subsubsection{Power generation by turbines using hydrogen}

Mitsubishi join the world's first innovative CCGT project in the Netherlands as original supplier of gas turbines. The project calls for operation of a fully hydrogen-powered CCGT unit in 2023, and MHPS will apply it's gas turbine expertise to investigate the technical feasibility of H2 firing. The MHPS succeeded in a demonstration experiment as of January 2018, when successfully burns $30 \%$ hydrogen mixed in a large gas turbine to produce equivalent of $0,7 \mathrm{TWh}$. The goal for MHPS is to put a "hydrogen-dedicated gas turbine ... into practical use by 2030.” [49, 50]

Obayashi Corporation and Kawasaki Heavy Industries are conducting a demonstration of the world's first urban hydrogen-fueled cogeneration system. The test in the city of Kobe is demonstrating the operation of an energy system within community (four nearby facilities, including a hospital) by supplying heat and electricity from hydrogen-fueled 1,7 MW gas turbine generator [51].

The turbine, under development by Mitsubishi Hitachi Power Systems, successfully completed the test using a $30 \%$ hydrogen fuel mix. It achieved a reduction in $\mathrm{CO}_{2}$ emissions of $10 \%$, compared to standard natural gas-fired power generation. The hydrogen-mix test forms part of a strategy by Japan's New Energy and Industrial Technology Development Organisation [52].

\section{End-User applications for hydrogen energy infrastructure}

\subsection{Transportation}

The global automotive market in 2016 estimated of 90 million units sold, the market for hydrogen cars was 2,500 units. Toyota reportedly has over 6,000 fuel cell vehicles in operation worldwide, and accounts for 
roughly 76 percent of hydrogen fuel cell vehicles sold globally, followed by Honda (13 percent), and Hyundai (11 percent). In Japan Toyota's FCV Mirai (it's name mean «Future») costs 7.2-million yen after central government subsidy, or approximately $\$ 65,800$ [53, 54, 55].

Toyota will supply the 7-Eleven retail chain in Japan with 300 fuel cell trucks by 2020 (5 percent of its delivery fleet), starting in 2019, and plans to deliver hundred og fuel cell buses in advance of the 2020 Tokyo Olympic and Paralympic Games [56].

\subsection{Transportation}

Equipment for energy service supply in buildings

Miura, which is the top boiler manufacturer in Japan, has developed a $4.2 \mathrm{~kW}$ Solid Oxide Fuel Cell (SOFC) unit for commercial use, is characterised by $48 \%$ electrical efficiency and 90\% overall energy efficiency. The system is on sale since October 2017 [57].

"ENE-FARM" is the nickname given to the world's first fuel cell for practical home use that has made its debut in Japan. That is the positive outcome of the micro-CHP promotion project my METI [58].

Panasonic claims its 2015 fuel cell model achieves 95\% combined heat and electrical efficiency. Earlier models were estimated at $80 \%$ to $90 \%$, and manufacturers compare those efficiencies to grid efficiency of $35 \%$ to $40 \%$. The units operate in partnership with the grid, cycling on and off in response to the home's demand for electricity and hot water. Osaka Gas, which is offering fuel cell units in combination with rooftop solar power for new homes, claims 57\% reduction in household GHG emissions and a consumer savings of $¥ 129,000$ [59].

The average price of fuel cell based micro-CHP without installation cost in Japan is 28,000 USD per kW [60].

\subsection{Equipment for hydrogen transportation at ambient pressure and tempersture}

Performance of SPERA technology has been confirmed in 2014. A variety of verification tests for commercial use were conducted, spanning approximately 10,000 hours from April 2013 to November 2014, at the Chiyoda's demonstration plant in Yokohama. It has been confirmed that $\mathrm{MCH}$ can be hydrogenated with toluene with yields of over 99\%, while hydrogen is produced from the same $\mathrm{MCH}$ with yields of more than $98 \%$ through the dehydrogenation process [61].

\subsection{Distribution}

Hitachi is producing commercial hydrogen dispenser Neorise for 82MPa, with dimensions W1600 $\times$ D $5900 \times \mathrm{H} 2100 \mathrm{~mm}$, and capacity 0.1 - 3.6 $\mathrm{kg} / \mathrm{min}$. The 100MPa-class hydrogen compressors is available with capacity of $300 \mathrm{Nm}^{3} / \mathrm{h}$ and dimensions W2200×D5450×H2200mm [62, 63].
Iwatani has employed a new system that arranges major equipment into units and offers them as a single package for stationary-type hydrogen refueling station.

Site Area is approximately $834 \mathrm{~m}^{2}$ with off-site supply of compressed hydrogen, supply capacity 150 $\mathrm{Nm}^{3} / \mathrm{h}$ (capable of filling three fuel cell vehicles per hour), and filling pressure 82MPa [64].

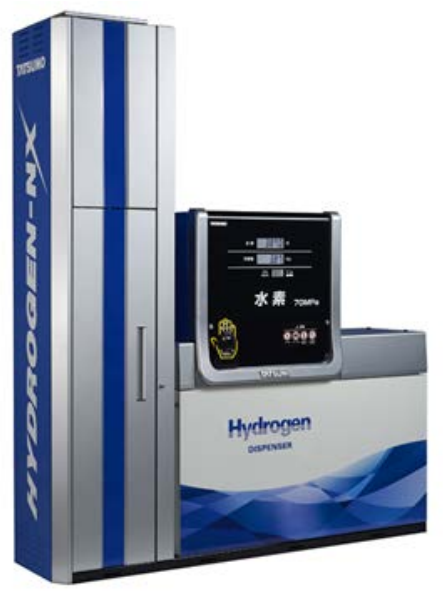

HYDROGEN-NX dispencer from Tatsuno, winner of the Good Design Award from the Japan Institute of Design Promotion in 2015, is on the market since April 2015 [65].

Fig. 7. Statistics of the ENE-FARM installations in Japan.

\section{Implications for the Russian Federation}

1) The development of hydrogen energy infrastructure will makes it possible to create a new type of energy carrier for the consumers of energy services, which is an effective supplement to electricity.

2) Since Japan is a technological and economic leader for the industrialised East Asian economies, including China, similar trends will be inherent within the East Asian region.

3) The development of hydrogen energy infrastructure is aimed at priority displacement of motor fuel in transportation and reduction of buildings' electricity and fuel consumption through the development of distributed generation.

4) The use of hydrogen as an energy carrier makes it possible to increase the capacity utilisation factor for renewables by means of alternative technologies outside electric power systems, as well as to create new consumer markets for renewable energy by reducing the demand for oil, coal and natural gas.

5) The production of hydrogen from hydrocarbon feedstocks will remain substantially more economical for several decades. Thus, the growth of hydrogen consumption as an energy carrier for end-use energy consumers will affect the traditional energy markets to a relatively small extent.

6) In the coming decades, the consumption of hydrogen as an energy carrier will be disproportionately less in comparison to traditional fossil fuels and even "environmentally friendly" 
biomass.

7) As a result of the innovative equipment market creation for the hydrogen energy infrastructure, new opportunities for the commercialisation of Russian technologies appears.

\section{ACKNOWLEDGMENT}

Preparation and publication of this article was supported by the Russian Academy of Sciences project AAAA-A17-117030310434-3.

\section{References}

1. BP Statistical Review of World Energy, [Электронный ресурс] . - Режим доступа: http://www.bp.com/statisticalreview, свободный. - Дата обращения: 15.05.2018.

2. IEO2017 by EIA, DOE US. - 14.09.2017, [Электронный ресурс] . - Режим доступа: www.eia.gov/outlooks/ieo, свободный. Дата обращения: 15.05.2018.

3. IEEJ Energy

Outlook 2018, http://eneken.ieej.or.jp/en/whatsnew/427.html.

4. http://global.kawasaki.com/en/stories/articles/vol54/

5. Working Group on CO2-Free Hydrogen Compiled a Report http://www.meti.go.jp/english/press/2017/03 07 003.html

6. Basic Hydrogen Strategy (key points) http://www.meti.go.jp/english/press/2017/pd f/1226_003a.pdf

7. Kawasaki road http://global.kawasaki.com/en/hydrogen/

8. Toshiba Reinforces Initiatives Toward a Hydrogen Economy http://www.toshiba.co.jp/about/press/2015 04/pr0601.htm\#PRESS

9. Products and services, Energy http://www.iwatani.co.jp/eng/products/index .html

10. 12 may 18; What is "SPERA HYDROGEN" system? https://www.chiyodacorp.com/en/service/sp era-hydrogen/innovations/

11. Panasonic Clean Energy Solution https://www.panasonic.com/global/corpora te/brand/story/clean_energy.html

12. Toshiba, Tohoku Electric Power and Iwatani Start Development of Large Hydrogen Energy System 15 may 18; $10 \quad 10$ Aug, 2017, http://www.toshiba.co.jp/about/press/2017_08 /pr1001.htm\#PRESS

13. [13] Toshiba, Tohoku Electric Power and Iwatani Start Development of Large Hydrogen Energy System 15 may 18; 10 Aug, 2017, http://www.toshiba.co.jp/about/press/2017_08 /pr1001.htm\#PRESS

14. Apr. 01, 2016; 12 may 18 Multi-company effort takes a step toward the future of hydrogen energy http://global.kawasaki.com/en/corp/newsroo $\underline{\mathrm{m} / \text { news/detail/?f=20160401_4614 }}$
15. Japan $\mathrm{H}_{2}$ Mobility, LLC established by eleven companies to accelerate deployment of hydrogen stations in Japan 15 may 18; March 5, 2018 https://global.honda/newsroom/news/2018/c18 0305eng.html

16. Japan'e ENE-FARM programme 10 oct 16 https://www.energyagency.at/fileadmin/dam/pdf/ projekte/gebaeude/Maruta.pdf

17. Japan continues efforts to embrace hydrogen fuel 5 may 18; Jan 4, 2018 http://www.hydrogenfuelnews.com/japancontinues-efforts-to-embrace-hydrogen$\underline{\text { fuel } / 8533787 /}$

18. Hydrogen energy navi http://www.hydrogennavi.jp/en/index.html

19. Compilation of the Revised Version of the Strategic Roadmap for Hydrogen and Fuel Cells [12 мая 18 г.; Release date March 22, 2016; Hydrogen and Fuel Cell Promotion Office, Agency for Natural Resources and Energy; http://www.meti.go.jp/english/press/2016/0 322_05.html]

20. Noriko Behling, Mark C. Williams, Shinsuke Managi, Fuel cells and the hydrogen revolution: Analysis of a strategic plan in Japan // Economic Analysis and Policy, http://dxx.doi.org/10.1016/j.eap.2015.10.002 01.10.2015 204-221 pp.

21. ENE-FARM installed 120,000 residential fuel cell units 5 may 18; September 21, 2015 https://www.h2international.com/2015/09/21/ene-farm-installed120000-residential-fuel-cell-units/

22. Fukushima Prefecture high on hydrogen for greener society May 14 2018; August 29, 2017 http://www.asahi.com/ajw/articles/AJ2017082 90001.html

23. Toshiba, Tohoku Electric Power and Iwatani Start Development of Large Hydrogen Energy System May $22 \quad$ 2018; 10 Aug, 2017, http://www.toshiba.co.jp/about/press/2017_08 /pr1001.htm\#PRESS

24. Sep 29, 2017 "Power to Gas" Demonstration to Start in

Hokkaido http://www.nedo.go.jp/english/news/AA5 en 100291.html

25. NEDO to Begin "Power to Gas" Demonstration in Hokkaido 2017-09-29 http://www.toyotatsusho.com/english/press/detail/170929_004155.htm $\underline{1}$

26. Toshiba to Start Demonstration Project with Iwatani to Establish Low-Carbon Hydrogen Supply Chain in Hokkaido May 242018 https://www.toshibaenergy.com/en/info/info2018_0524.htm

27. Toshiba Begins Operation of Independent Energy Supply System Utilizing Renewable Energy and Hydrogen 20 aпр 201525 мая 18 http://www.toshiba.co.jp/about/press/2015_04/pr 2001.htm 
28. Japanese companies plan hydrogen supply chain project 30 may 18; JULY 27, 2017 https://www.reuters.com/article/us-japanhydrogen/japanese-companies-plan-hydrogensupply-chain-project-idUSKBN1AC0WN

29. The World's First Global Hydrogen Supply Chain Demonstration Project 30 may 18; dec 24 2017 http://www.mitsui.com/jp/en/release/2017/122 4164_10832.html

30. NEDO to Start a Full-scale Demonstration Project on the World's First Global Hydrogen Supply Chain 31 may 18; July 27, 2017 http://www.nedo.go.jp/english/news/AA5en_1 00278.html

31. Consortium to import Australian hydrogen to Japan 30 may 18; APR 12, 2018 https://www.japantimes.co.jp/news/2018/04/12 /business/consortium-import-australian-hydrogenjapan/\#.Ww6a2S2FTUI

32. Kawasaki ship designs support Japan's hydrogensociety plans 19 Mar 2017 http://www.lngworldshipping.com/news/view, kawasaki-ship-designs-support-japanshydrogensociety-plans_46421.htm

33. [15] Japan $\mathrm{H}_{2}$ Mobility, LLC established by eleven companies to accelerate deployment of hydrogen stations in Japan 15 may 18; March 5, 2018 https://global.honda/newsroom/news/2018/c18 0305eng.html

34. Hydrogen highway (Japan) 31 may 18 access; https://infogalactic.com/info/Hydrogen_hig hway_(Japan)

35. Hydrogen fuel finds more support in Japan 30 may 18 ; July 3 , 2015 http://www.hydrogenfuelnews.com/hydrogenfuel-finds-more-support-in-japan/8522629/

36. Japan: Forcing the SOFC technology 25 may 18; 6 mar $18 \quad$ http://www.h2international.com/2018/03/06/japan-forcing-thesofc-technology/

37. Hydrogen fuel delivery service is coming to Japan Sep

11 , 2017 http://www.hydrogenfuelnews.com/hydrogenfuel-delivery-service-is-coming-to-japan/8532913/

38. New hydrogen fuel stations from Honda are coming to Japan 25 may 18; Oct 27, 2017 http://www.hydrogenfuelnews.com/newhydrogen-fuel-stations-from-honda-are-coming-tojapan/8533282/

39. Iwatani Opens the Commercial Hydrogen Refueling Station, the First in Okayama Prefecture April 26, 201815

may

18 http://www.iwatani.co.jp/img/eng/pdf/newsreleas e/88/20180426_news_e1.pdf

40. Hydrogen fuel finds more support in Japan 30 may 18 ; July

3 , 2015 http://www.hydrogenfuelnews.com/hydrogenfuel-finds-more-support-in-japan/8522629/
41. NEDO Launches a Demonstration Test of Solid Oxide Fuel Cell Systems in Osaka 30 may 18; March 2017, http://www.nedo.go.jp/english/news/AA5en 100200.html

42. Toyota Expands Hydrogen Fuel Cell Production in Japan May 24, 2018; May 29, 2018 http://www.hybridcars.com/toyota-expandshydrogen-fuel-cell-production-japan/

43. Toshiba's Autonomous Off-grid Hydrogen Energy System H2One ${ }^{\mathrm{TM}}$ Now Providing Power at JR Station in Japan April 17, 2017 https://www.businesswire.com/news/home/20 $\underline{170416005018 / \text { en/Toshibas-Autonomous-Off-grid- }}$ Hydrogen-Energy-System-H2One\%E2\%84\%A2

44. Toshiba's Pure Hydrogen Fuel Cell System Now Providing Power and Hot Water to New Hotel 30 may 18; $\quad$ https://www.toshibaenergy.com/en/info/info2018_0530

45. Toshiba's $\mathrm{H}_{2}$ One system becomes operational at Musashi-Mizonokuchi Station in Japan 17 APRIL 2017 https://www.railwaytechnology.com/news/newstoshibas-h2one-systembecomes-operational-at-japans-railway-station$\underline{5788378 /}$

46. Toshiba to Supply $\mathrm{H}_{2}$ One ${ }^{\mathrm{TM}}$ Hydrogen Energy System to Tokyu Construction May 25, 2018; 20 Jun,

2017 https://www.toshiba.co.jp/about/press/2017_06 /pr2001.htm

47. Toshiba's Pure Hydrogen Fuel Cell System Now Providing Power and Hot Water to New Hotel 30 may 18; https://www.toshibaenergy.com/en/info/info2018_0530.htm

48. Delivery of a Hydrogen Generation System for Fuel Cell Forklifts Apr 10, 2017 https://www.hitachizosen.co.jp/english/news/2 017/04/002629.html

49. MHPS to participate in hydrogen conversion at Dutch natgas plant January 19, 2018 https://www.mhps.com/news/20180308.html

50. The hydrogen gas turbine, successfully fired with a $30 \%$ fuel mix, is a major step towards a carbon-free society April 26, 2018 https://www.mhps.com/special/hydrogen/articl e 1/index.htm

51. NEDO Conducts World's First Technology Demonstration for Hydrogen-fueled Cogeneration System in Urban Areas Dec 11, 2017 http://www.nedo.go.jp/english/news/AA5en_1 00348.html

52. Mitsubishi Heavy IndustriesVoice: Hydrogen's Vast Potential To Make Power Generation Cleaner And More Efficient 30 may 18; 21 mar 18г http://www.cetusnews.com/business/MitsubishiHeavy-IndustriesVoice--Hydrogen-s-Vast-PotentialTo-Make-Power-Generation-Cleaner-And-MoreEfficient.SkR2vBx9G.html 
53. Toyota Expands Hydrogen Fuel Cell Production in Japan May 28, 2018; May 24, 2018 http://www.hybridcars.com/toyota-expandshydrogen-fuel-cell-production-japan/

54. 2018 Toyota Mirai fuel cell vehicle May 28, 2018; 10, https://ssl.toyota.com/mirai/fcv.html

55. Fukushima Prefecture high on hydrogen for greener society May 28, 2018; 10, August 29, 2017 http://www.asahi.com/ajw/articles/AJ2017082 90001.html

56. Toyota to make fuel cell trucks for Seven-Eleven Japan May 28, 2018; 10, 2017 https://asia.nikkei.com/Business/Deals/Toyotato-make-fuel-cell-trucks-for-Seven-Eleven-Japan

57. NEDO news release 30 may 18; Aug 7 17 http://www.nedo.go.jp/english/news/AA5en_100 255.html

58. Japan'e ENE-FARM programme 10 oct 16 https://www.energyagency.at/fileadmin/dam/pdf/ projekte/gebaeude/Maruta.pdf

59. ENE-FARM installed 120,000 residential fuel cell units September 21, 2015 http://www.h2international.com/2015/09/21/ene-farm-installed120000-residential-fuel-cell-units/

60. Home-use Fuel Cell (ENE-FARM) http://www.jlpgas.gr.jp/en/appliances/

61. Performance of 10,000 hours of operation in Chiyoda's demo plant 12 may 18; https://www.chiyodacorp.com/en/service/sperahydrogen/demo-plant/

62. Hydrogen Dispenser http://www.hitachiautomotive-mm.com/en/products/ecodispenser/hydrogen/

63. High-Pressure Hydrogen Compressors http://www.hitachiinfra.com.sg/services/social_infrastructure_systems/ compressor/reciprocating/hydrogen.html

64. Iwatani Opens the Commercial Hydrogen Refueling Station, the First in Okayama Prefecture April 26, 201815 may 18 http://www.iwatani.co.jp/img/eng/pdf/newsreleas e/88/20180426_news_e1.pdf

65. Good Design Award http://www.gmark.org/award/describe/42613 